\title{
The Purification and Properties of the $\mathrm{L}$-Threonine Deaminase of the Rumen Micro-organism LG1
}

\author{
BY D. J. WALKER* \\ Agricultural Research Council Unit for Microbiology, Department of Microbiology, University of Sheffield
}

(Received 8 January 1958)

The micro-organism LC, isolated from the sheep rumen by Elsden, Volcani, Gilchrist \& Lewis (1956), ferments a variety of substrates to yield volatile fatty acids (Elsden \& Lewis, 1953). Washed cells of the organism fermented L-threonine and L-serine. Hydrogen, carbon dioxide and ammonia were produced from both substrates and, in addition, propionate was formed from threonine and acetate from serine (Lewis \& Elsden, 1955). Acetone-dried powders converted L-threonine into a keto acid, identified as 2-oxobutyrate, as well as the above end products. When 2-oxobutyrate was used as substrate, hydrogen, carbon dioxide and propionate were the principal products. These experiments suggested that a threonine deaminase is involved and that 2-oxobutyrate is an intermediate in threonine fermentation.

$$
\begin{aligned}
\mathrm{CH}_{3} \cdot \mathrm{CH}(\mathrm{OH}) \cdot \mathrm{CH}\left(\mathrm{NH}_{2}\right) \cdot \mathrm{CO}_{2} \mathrm{H} & \rightarrow \mathrm{CH}_{3} \cdot \mathrm{CH}_{2} \cdot \mathrm{CO} \cdot \mathrm{CO}_{2} \mathrm{H}+\mathrm{NH}_{3} .
\end{aligned}
$$

Similarly, pyruvate appears to be an intermediate in the breakdown of $\mathrm{L}$-serine by this organism.

The deamination of threonine by both animal tissues and microbes has been studied by a number of workers in recent years, particularly with respect to cofactor requirements. The L-threonine deaminase of Neurospora has been completely resolved by Yanofsky \& Reissig (1953) and shown to require pyridoxal phosphate for its action. Deaminases for both $\mathrm{D}$ - and L-threonine have been found in Escherichia coli, and Metzler \& Snell (1952) have shown a pyridoxal phosphate requirement for the D-threonine deaminase. However, the situation with regard to the enzyme specific for the L-isomer in $E$. coli is more complicated. Wood \& Gunsalus (1949) found that adenosine 5-phosphate (AMP) and glutathione (GSH) were necessary for the maximum activity of their partially purified enzyme. These results were not confirmed by Umbarger \& Brown (1956), who studied crude extracts of $E$. coli and found no effect with AMP or GSH or both, but some increase in activity with pyridoxal phosphate. More recent studies by Umbarger \& Brown (1957) indicate that two Lthreonine deaminases may be present in $E$. coli

* Present address: C.S.I.R.O. Division of Biochemistry, University of Adelaide, South Australia. extracts, one requiring AMP, GSH and pyridoxal phosphate for full activity [cf. the findings of Sayre \& Greenberg (1956) with the sheep-liver enzyme], and the other requiring only pyridoxal phosphate.

This paper describes both the purification and properties of the L-threonine deaminase of LC and the almost complete resolution of the purified enzyme. A preliminary report of these findings has already been published (Walker, 1957).

\section{MATERIALS AND METHODS}

\section{Materials}

Growth of the organism. LC strain 1 (LC1) of the rumen organism described by Elsden et al. (1956) was used throughout the present work.

Stock cultures (transferred fortnightly) were maintained on semi-solid medium containing $1.4 \%(\mathrm{w} / \mathrm{v})$ of sodium lactate, $0.4 \%$ of Difco yeast extract, $0.02 \%$ of thioglycollic acid and $0.2 \%$ of agar in tap water, $\mathrm{pH} \mathbf{7 . 4}$. Portions $\left(10 \mathrm{ml}\right.$.) in $\frac{5}{8}$ in. $\times 5$ in. test tubes closed with cotton-wool plugs were sterilized by autoclaving at 15lb./in. ${ }^{2}$ for $20 \mathrm{~min}$. Oxygen was removed from the medium, immediately before inoculation, by heating at $100^{\circ}$ for $10 \mathrm{~min}$. and cooling. With this technique, a vigorously growing culture was obtained in 8-12 hr. All cultures were grown at $37^{\circ}$.

The method for large-scale cultivation of the organism was devised in this laboratory by Dr J. L. Peel (unpublished work) and was based on the methods used by Stadtman \& Barker (1949) with Clostridium kluyveri. Commercial, 10 gal. iron drums, adequately cleaned, were used as culture vessels. The outlet at the top of the drum was provided with a rubber bung fitted with two glass tubes. One of these reached the bottom of the drum and was the inlet for gassing; the other, the gas outlet, terminated at the lower surface of the bung. This accessory was wrapped and sterilized separately. The drum was almost filled with tap water, closed with a cotton plug and sterilized by autoclaving for $2 \mathrm{hr}$. at $20 \mathrm{lb}$./in. ${ }^{2}$.

The medium employed for large-scale cultivation contained $1 \%(w / v)$ of corn-steep liquor (a gift from the Distillers Co. Ltd., Wimbledon, Surrey), $1.4 \%$ of sodium lactate and $0.02 \%$ of sodium dithionite as reducing agent. The individual components of the medium were sterilized separately in concentrated solution and added aseptically to the water in the drum. Sodium lactate was sterilized as an approx. $35 \%$ solution by autoclaving at $15 \mathrm{lb}$./in. ${ }^{2}$ for $30 \mathrm{~min}$. A $10 \%(\mathrm{w} / \mathrm{v})$ solution of sodium dithionite was made up immediately before inoculation and sterilized by filtration. 
Difficulty was experienced in sterilizing the corn-steep liquor, which contained a thermophilic rod-shaped organism resistant to autoclaving at neutral $\mathrm{pH}$. The following procedure was therefore adopted: the corn-steep liquor, which is approx. N-acid, was diluted with an equal volume of water and autoclaved for $45 \mathrm{~min}$. at $20 \mathrm{lb}$./in. ${ }^{2}$. The solution was then neutralized to $\mathrm{pH} \mathbf{7 \cdot 4}$ with $\mathrm{NaOH}$ and filtered to remove precipitated material, after which it was autoclaved for $20 \mathrm{~min}$. at $15 \mathrm{lb}$./in. ${ }^{2}$. A further precipitate formed and was allowed to settle. The supernatant was poured into the drum aseptically and the precipitate discarded.

The inoculum was 21 . of vigorously growing culture, grown in a $3 \mathrm{l}$. flask under an atmosphere of $\mathrm{H}_{2}-\mathrm{CO}_{2}(95: 5)$. The arrangement for gassing was such that the culture could be expelled from the flask by reversing the direction of the flow of gas. The medium, which was the same as that used for drum-scale culture, was inoculated with a tube of cells growing vigorously in the semi-solid medium. After growth for $16 \mathrm{hr}$, the $2 \mathrm{l}$. of culture was transferred to the drum by displacement with the $\mathrm{H}_{2}-\mathrm{CO}_{2}$ gas mixture. The drum was flushed with the $\mathrm{H}_{2}-\mathrm{CO}_{2}$ mixture and incubated at $37^{\circ}$. Growth was complete in $12-16 \mathrm{hr}$. Considerable quantities of $\mathrm{H}_{2}$ and $\mathrm{CO}_{2}$ are produced during the growth of LC, and to avoid the possibility of an explosion the gases were led out of the confined space of the constant-temperature room via a water trap.

With the large inoculum used, strict asepsis was not obligatory; if the drum was well washed and filled with hot water from the tap, the autoclaving could be dispensed with. Similarly, the medium constituents could be added through a sterilized funnel without undue risk of contamination. When these procedures were adopted, however, the purity of the culture was checked by microscopic examination. This is a reasonably effective criterion of culture purity, as the morphology of the organism is highly characteristic (Elsden et al. 1956).

After growth the cultures were harvested with the Sharples Super centrifuge, washed once with freshly boiled, cooled water and dried in vacuo over $\mathrm{H}_{2} \mathrm{SO}_{4}$ at room temperature. The dried cells were pulverized and stored at $-20^{\circ}$.

Reagents. The phosphate buffers used were prepared from solutions of $\mathrm{M}-\mathrm{KH}_{2} \mathrm{PO}_{4}$ and $\mathrm{M}-\mathrm{Na}_{2} \mathrm{HPO}_{4}$. All reagents used were of A.R. grade, except those listed below.

DL- and L-Threonine were obtained from L. Light and Co. Ltd. (Colnbrook, Bucks). The purity was checked by the periodate method of Shinn \& Nicolet (1941) and the samples were found to contain $99 \%$ of 2 -amino-3-hydroxy acid. No impurities were detected on chromatography in butanol-acetic acid-water (4:1:5) (upper phase mobile) and phenol-water (mutually saturated, the upper phase mobile). L-Serine was obtained from the Nutritional Biochemicals Corpn. (Cleveland, Ohio, U.S.A.). 2-Oxobutyric acid was prepared from 2-aminobutyric acid by the method of Keilin \& Hartree (1936). The product was redistilled in vacuo, and the oily liquid so obtained stored at $-20^{\circ}$. Solutions of the sodium salt were prepared by neutralizing solutions of the acid with approx. $2 \mathrm{~N}-\mathrm{NaOH}$. When assayed with yeast carboxylase (Umbreit, Burris \& Stauffer, 1949), the yield of $\mathrm{CO}_{2}$ was theoretical. Crystalline sodium pyruvate was prepared by the method of Robertson (1942), except that the commercial pyruvic acid was first redistilled in vacuo. The final product gave a theoretical yield of $\mathrm{CO}_{2}$ in the yeast carboxylase system. Pyridoxal phosphate was kindly supplied by Dr Morrison of Roche Products Ltd. (Welwyn Garden City, Herts). Calcium phosphate gel-cellulose columns were prepared by mixing calcium phosphate gel suspension (McIntire, Palmer \& Marshall, 1945) with dry powdered cellulose to give a dry weight ratio of one part of calcium phosphate gel to five of cellulose. Glass columns $2 \mathrm{~cm}$. in diameter were filled to a depth of about $12 \mathrm{~cm}$. and the material was allowed to settle under gravity, finally giving a column about $8 \mathrm{~cm}$. high.

\section{Methods}

Assay of enzymic activity. The unit of enzymic activity was defined as that amount of enzyme necessary to catalyse the formation of $1 \mu$ mole of 2 -oxo acid under the standard conditions of assay. The conditions employed for assay were as follows: a sample of the enzyme preparation was incubated with $0.7 \mathrm{ml}$. of $0.1 \mathrm{M}$-borate buffer, $\mathrm{pH} 9.5$, $10 \mu \mathrm{g}$. of pyridoxal phosphate and $20 \mu$ moles of $\mathrm{L}$-threonine, in a total volume of $1 \mathrm{ml}$. The reaction was allowed to proceed for $5 \mathrm{~min}$. at $37^{\circ}$ and stopped by the addition of $0.2 \mathrm{ml}$. of $10 \mathrm{~N}-\mathrm{H}_{2} \mathrm{SO}_{4}$. After making the volume to $3 \mathrm{ml}$. the precipitated protein was centrifuged off and a sample of the supernatant assayed for keto acid by the extraction method of Friedemann \& Haugen (1943).

The specific activity of an enzyme preparation was defined as units/mg. of protein.

Protein. This was determined by the method of Stadtman, Novelli \& Lipmann (1951), on the assumption that $0.1 \mathrm{mg}$. of protein gives an optical density of 0.1 at $340 \mathrm{~m} \mu$ under their conditions. This method was used whenever specificactivity determinations were made.

Ammonia. This was determined by the method of Conway \& O'Malley (1942).

\section{RESULTS}

Table 1 summarizes the results obtained from the purification procedure adopted.

Extraction of the dried cells. Vacuum-dried cells of LC 1 were suspended in $0.01 \mathrm{M}$-phosphate buffer, $\mathrm{pH} 7.8$ ( $1 \mathrm{~g}$. of cells $/ 10 \mathrm{ml}$. of buffer), and the suspension was stirred at $37^{\circ}$ for $1 \mathrm{hr}$. with a magnetic stirrer. All subsequent operations were carried out below $5^{\circ}$. Cell debris was removed by centrifuging at $-2^{\circ}$ for $15 \mathrm{~min}$. at $24000 \mathrm{~g}$ in an International refrigerated centrifuge. The clear, yellow-green supernatant contained the deaminase activity.

Protamine sulphate treatment. The crude extract was treated with a solution containing $15 \mathrm{mg}$. of protamine sulphate $/ \mathrm{ml}$; $1 \mathrm{ml}$. of this solution was added for each $100 \mathrm{mg}$. of extract protein and the mixture stirred for $15 \mathrm{~min}$; the precipitate was then removed by centrifuging and discarded.

Ammonium sulphate fractionation. Solid $\left(\mathrm{NH}_{4}\right)_{2} \mathrm{SO}_{4}$ was first added to $40 \%$ saturation, the amount required being calculated from the nomogram of Dixon (1953). The mixture was then stirred for $15 \mathrm{~min}$. The precipitate was removed by centrifuging and discarded. Further addition of 
Table 1. Purification of $\mathrm{L}$-threonine deaminase

\begin{tabular}{|c|c|c|c|}
\hline Purification stage & $\begin{array}{l}\text { Total } \\
\text { activity } \\
\text { (units) }\end{array}$ & $\begin{array}{l}\text { Total } \\
\text { protein } \\
\text { (mg.) }\end{array}$ & $\begin{array}{c}\text { Specific activity } \\
\text { (units/mg. } \\
\text { of protein) }\end{array}$ \\
\hline Crude extract from $3 \mathrm{~g}$. of dried cells & 1330 & 266 & $5 \cdot 0$ \\
\hline $\begin{array}{l}\text { After treatment with protamine } \\
\text { sulphate }\end{array}$ & 1330 & 240 & $5 \cdot 5$ \\
\hline $\begin{array}{l}\text { Pooled fractions from gradient } \\
\text { elution with }\left(\mathrm{NH}_{4}\right)_{2} \mathrm{SO}_{4}\end{array}$ & 1298 & $59 \cdot 6$ & $22 \cdot 2$ \\
\hline $\begin{array}{l}\text { Individual fractions from calcium } \\
\text { phosphate gel-cellulose column* }\end{array}$ & $\begin{array}{l}50 \\
31 \\
39 \\
60 \\
66 \\
56 \\
40 \\
23\end{array}$ & $\begin{array}{l}0.30 \\
0.06 \\
0 \cdot 17 \\
0.49 \\
0 \cdot 11 \\
0.11 \\
0.40 \\
0.17\end{array}$ & $\begin{array}{l}166 \\
516 \\
230 \\
122 \\
600 \\
508 \\
100 \\
135\end{array}$ \\
\hline
\end{tabular}

solid $\left(\mathrm{NH}_{4}\right)_{2} \mathrm{SO}_{4}$ was made until the solution was $65 \%$ saturated. After stirring for $15 \mathrm{~min}$. the precipitate was centrifuged off and suspended in $70 \%$ saturated $\left(\mathrm{NH}_{4}\right)_{2} \mathrm{SO}_{4}$ solution.

The precipitated protein was then fractionated by concentration-gradient elution, the method of Schwimmer (1953) as modified by Sayre \& Greenberg (1956) being used. The suspension of protein in $70 \%$ saturated $\left(\mathrm{NH}_{4}\right)_{2} \mathrm{SO}_{4}$ solution was mixed with Celite 535 (Johns-Manville Co., London) to form a thin slurry, which was then placed on the top of a column of Celite $535(5 \mathrm{~cm}$. diam. $\times 8 \mathrm{~cm}$. high) made up in $70 \%$ saturated $\left(\mathrm{NH}_{4}\right)_{2} \mathrm{SO}_{4}$. The column was attached to a conical closed flask containing $300 \mathrm{ml}$. of $70 \%\left(\mathrm{NH}_{4}\right)_{2} \mathrm{SO}_{4}$ stirred by a magnetic stirrer. The gradient was established by running in $0 \cdot 05 \mathrm{~m}$-phosphate buffer, $\mathrm{pH} 7 \cdot 8$. Fractions of approx. $20 \mathrm{ml}$. were collected, the protein contents of which were followed by measuring the density at $280 \mathrm{~m} \mu$ in the Unicam SP. 500 spectrophotometer. Protein with deaminase activity was eluted in a fairly sharp band with nearly constant specific activity.

Absorption and elution from calcium phosphate gel-cellulose column. The active fractions from the gradient elution column were combined and the protein was precipitated by adding solid $\left(\mathrm{NH}_{4}\right)_{2} \mathrm{SO}_{4}$ to saturation. The precipitate was removed by centrifuging, dissolved in a small volume of water and the solution placed on a calcium phosphate gelcellulose column, which had been washed for 4-5 hr. with 0.01 M-phosphate buffer, pH 7.8, containing $0.2 \%$ of $\mathrm{NaCl}$ (Swingle \& Tiselius, 1951). Development was first carried out with $0.04 \mathrm{M}$ phosphate buffer, pH 7.8, containing $0.2 \%$ of $\mathrm{NaCl}$, and a yellow-green band of protein which had no deaminase activity was eluted. When the optical density $(280 \mathrm{~m} \mu)$ of the fractions had fallen to a constant low value $(0 \cdot 02)$, the eluting buffer was changed to $0.06 \mathrm{M}$-phosphate buffer, $\mathrm{pH} 7 \cdot 8$, containing $0.2 \%$ of $\mathrm{NaCl}$. Protein with deaminase activity was then eluted in a rather diffuse band. The specific activities of the fractions containing active protein were variable, probably because the method of estimating protein was not sufficiently sensitive with the small amounts of protein present (about $0.1 \mathrm{mg} . / 5 \mathrm{ml}$. fraction). The specific activities of the fractions used in subsequent experiments averaged about 500 units/mg. of protein. Attempts to concentrate the small amounts of protein thus obtained by precipitation with $\left(\mathrm{NH}_{4}\right)_{2} \mathrm{SO}_{4}$ resulted in up to $75 \%$ loss of activity. For this reason, the untreated fractions were stored at $-15^{\circ}$, where the activity did not fall off appreciably over 3-4 weeks.

The purification procedure was reproducible except that different batches of dried cells gave extracts of varying specific activity. This affected the degree of purification brought about by protamine sulphate treatment, which varied from $1 \cdot 1$ to $2 \cdot 5$-fold.

Except in a few preliminary experiments, the properties of the enzyme were studied with preparations obtained by the above purification procedure.

\section{Properties of the enzyme}

Lewis \& Elsden (1955), using acetone-dried powers of LC3, studied the effect of $\mathrm{pH}$ on deamination of threonine and also isolated the deamination product as the 2:4-dinitrophenylhydrazine derivative. Repetition of these experiments with crude extracts of vacuum-dried cells showed that the optimum $\mathrm{pH}$ for 2-oxo acid production from threonine was over the range $\mathrm{pH} \mathrm{9.0-10 \cdot 0}$ (Fig. 1), whereas Lewis \& Elsden (1955) found quite a sharp peak at $\mathrm{pH} 9 \cdot 0$. Over the range pH 7.0-10.0, the production of 2-oxo acid shows little sensitivity to changes in $\mathrm{pH}$. 
Isolation, as the 2:4-dinitrophenylhydrazone, of the 2-oxo acid produced from threonine by crude extracts of vacuum-dried cells confirmed the findings of Lewis \& Elsden (1955) that the product is 2-oxobutyric acid. The product melted at $196^{\circ}$ (uncorr.) and did not depress the melting point of an authentic sample of the 2:4-dinitrophenylhydrazone of 2-oxobutyric acid.

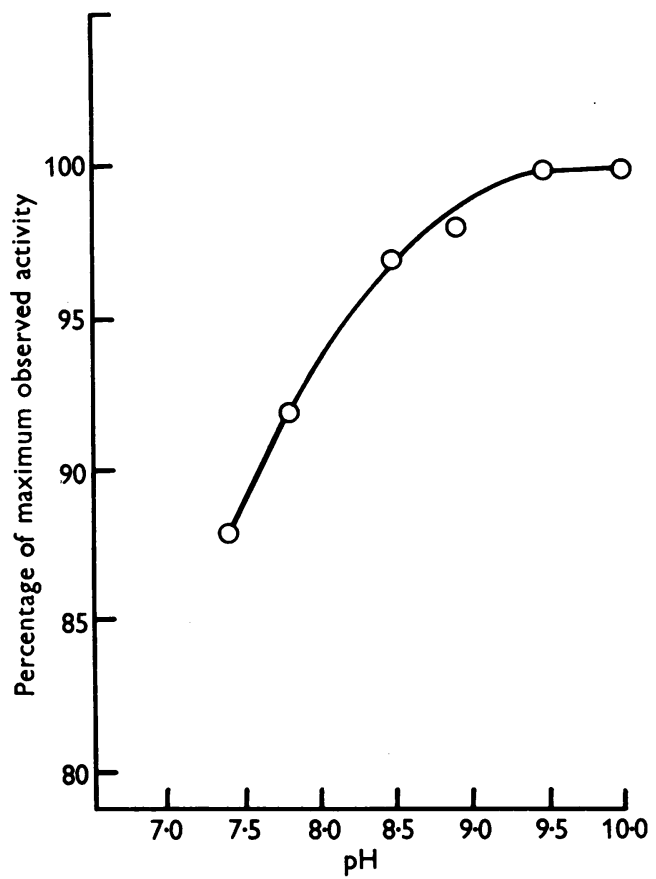

Fig. 1. Effect of $\mathrm{pH}$ on the initial rate of 2-oxo acid production from L-threonine by a crude extract of LCl. Reaction mixture was as described in the text. Phos: phate buffer was used at $\mathrm{pH} \mathbf{7 . 4}$ and $\mathbf{7 \cdot 8}$ and borate buffer between $\mathrm{pH} 8.5$ and $10 \cdot 0$. Rates were calculated from the portion of the progress curve where 2-oxo acid production was linear (0-10 min.).
With a crude extract of vacuum-dried cells, the production of 2-oxo acid and ammonia from threonine was followed. The two products appeared simultaneously and in equal amounts (Table 2).

Activity towards L-serine. Throughout the purification, threonine was always deaminated more rapidly than serine. The ratio of serine deaminase activity to threonine deaminase activity remained reasonably constant (Table 3 ). These results agree with those of Wood \& Gunsalus (1949) and Yanofsky \& Reissig (1953) with the L-threonine deaminase of $E$. coli and Neurospora respectively.

Effect of substrate concentration. An enzyme preparation purified approximately 50-fold (specific activity 340 units/mg. of protein) was used to study the effect of substrate concentration on the initial rate of deamination of $\mathrm{L}$-serine and $\mathrm{L}$-threonine. Data plotted by the method of Lineweaver \& Burk (1934) gave $K_{m}$ values of 6.8 mM and $3.0 \mathrm{~mm}$ for serine and threonine respectively.

Effect on D-threonine. DL-Threonine was deaminated at only $45 \%$ of the rate at which Lthreonine was deaminated. In three fermentation

\section{Table 2. Equivalence of ammonia and 2-oxo acid formed}

Crude extract $(0.1 \mathrm{ml}$.) was incubated with $0.5 \mathrm{ml}$. of $0 \cdot 1 \mathrm{~m}$-borate buffer, $\mathrm{pH} 9.5$, in a stoppered test tube fitted with a side arm which contained $0.2 \mathrm{ml}$. of $0.1 \mathrm{M}-\mathrm{L}$-threonine. The side-arm contents were tipped in after equilibration of the tubes at $37^{\circ}$ and reaction was stopped at the time indicated by quickly adding $0.2 \mathrm{ml}$. of $10 \mathrm{~N}-\mathrm{H}_{2} \mathrm{SO}_{4}$ via the stopper. Vessels were kept closed and shaken from time to time over $15 \mathrm{~min}$. to ensure complete trapping of ammonia.

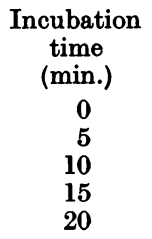

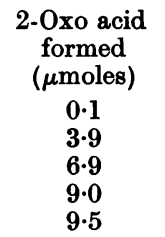

\section{Table 3. Relative activities of deaminase preparations towards $\mathrm{L}$-serine and $\mathrm{L}$-threonine}

Enzyme preparation $(0.1 \mathrm{ml}$.) was assayed in open tubes as described under Methods; L-serine (20 $\mu$ moles) was substituted for threonine where necessary. Keto acid production in the absence of substrate was negligible.

\begin{tabular}{cccc}
$\begin{array}{c}\text { Specific } \\
\text { activity } \\
\text { of enzyme } \\
\text { preparation }\end{array}$ & $\begin{array}{c}\text { 2-Oxo acid formed } \\
\text { ( } \mu \text { moles) }\end{array}$ & \\
\cline { 2 - 3 } (units/mg. \\
of protein) & $\begin{array}{c}\text { L-threonine } \\
(a)\end{array}$ & $\begin{array}{c}\text { From } \\
\text { L-serine }\end{array}$ & $\begin{array}{c}\text { Ratio } \\
(a / b)\end{array}$ \\
2.1 & 8.6 & $2 \cdot 6$ & 3.3 \\
4.6 & 1.4 & 0.3 & 4.6 \\
13.5 & 5.8 & 1.07 & 5.4 \\
290 & 0.82 & 0.15 & 5.5
\end{tabular}

Crude extract

After treatment with protamine sulphate

After gradient elution with $\left(\mathrm{NH}_{4}\right)_{2} \mathrm{SO}_{4}$

After calcium phosphate gel-cellulose column
290

* Enzyme preparations used in this experiment were selected at random from different batches at the various stages of purification. 
experiments it was found that the yields of ammonia from DL-threonine were 60, 57 and $54 \%$ of the theoretical. These results indicate that the threonine deaminase of LC is inhibited by $D$ threonine and that the enzyme is specific for the L-isomer.

Inhibitors. Yanofsky \& Reissig (1953) reported inhibition of the L-threonine deaminase of Neurospora by cyanide and hydroxylamine. A partially purified enzyme (specific activity 130 units $/ \mathrm{mg}$. of protein) from LCl was inhibited 6 and $43 \%$ by 0.5 and $50 \mathrm{~mm}-\mathrm{KCN}$ and $64 \%$ by $0.5 \mathrm{~mm}$-hydroxylamine.

Cofactor requirement. In agreement with the findings of both Yanofsky \& Reissig (1953) and Sayre \& Greenberg (1956), no significant dissociation of the coenzyme-apoenzyme complex was observed during the purification procedure and no resolution was obtained on dialysis. Yanofsky \& Reissig (1953) obtained a resolved preparation by storing fresh mycelium of Neurospora in the deepfreeze for several weeks. Vacuum-dried cells of LC 1 stored in the same way for up to 4 years did not, on extraction, give enzyme preparations in which deaminase activity was significantly increased by the addition of pyridoxal phosphate. The deaminase activity of the extracts was comparable with that of newer batches of cells. However, with a preparation which had been made by treating a crude extract with $\left(\mathrm{NH}_{4}\right)_{2} \mathrm{SO}_{4}$ to $90 \%$ saturation, freeze-drying the precipitate and storing at $-20^{\circ}$ for 9 months, the rate of formation of 2-oxo acid from threonine was nearly doubled by adding $100 \mu \mathrm{g}$. of pyridoxal phosphate to the reaction mixture. The effect of freeze-drying on other preparations was then studied.

A crude extract of vacuum-dried cells was freeze-dried without further treatment. Portions of the dry material were stored at $+4^{\circ}$ and $-20^{\circ}$ and tested periodically for stimulation of deaminase activity by pyridoxal phosphate. Over a period of several weeks, no stimulation of 2-oxo acid production was observed. Results with purified enzyme preparations were somewhat variable, but a marked resolution was accomplished. Freezedrying the purified enzyme without previous additions resulted in the loss of most of the activity, which was not restored by adding pyridoxal phosphate or glutathione or both together, or by boiled crude extract. When glutathione was added to a purified preparation (specific activity 378 units/mg. of protein) to a final concentration of $4 \mathrm{~mm}$ and the solution freeze-dried, addition of $10 \mu \mathrm{g}$. of pyridoxal phosphate $/ \mathrm{ml}$. of reaction mixture doubled the deaminase activity of the enzyme so treated. A control sample of the enzyme preparation, freeze-dried without prior addition of GSH, was not stimulated by addition of pyridoxal phosphate. The experiments of Sayre \& Greenberg (1956) showed that dilute solutions of their purified deaminase were protected from denaturation by $\left(\mathrm{NH}_{4}\right)_{2} \mathrm{SO}_{4}$. The effect of freeze-drying purified preparations in the presence of $\left(\mathrm{NH}_{4}\right)_{2} \mathrm{SO}_{4}$ was therefore studied, and some resolution was obtained when preparations were freeze-dried in the presence of either $\left(\mathrm{NH}_{4}\right)_{2} \mathrm{SO}_{4}$ or GSH. Greater resolution was obtained when both $\left(\mathrm{NH}_{4}\right)_{2} \mathrm{SO}_{4}$ and GSH were added before freeze-drying. The extent of dissociation of the coenzyme from the apoenzyme varied from preparation to preparation, but apparent resolutions [(increase in activity obtained by addition of pyridoxal phosphate/total activity in presence of pyridoxal phosphate) $\times 100$ ] of 75 and $94 \%$ have been observed. The results of a number of freeze-drying experiments are given in Table 4.

Effect of other cofactors on reactivation of the apoenzyme. Wood \& Gunsalus (1949) found that the enzyme from $E$. coli required both GSH and AMP. In order to study the effects of GSH and AMP on the enzyme from LCl a purified preparation, partially resolved by freeze-drying in the presence of $\left(\mathrm{NH}_{4}\right)_{2} \mathrm{SO}_{4}$ alone, was used. Neither GSH nor

Table 4. Effect of adding ammonium sulphate and glutathione before freeze-drying on the resolution of the enzyme

Activity of the preparations was determined in the usual assay system (see Methods) in the presence and absence of $10 \mu \mathrm{g}$. of pyridoxal phosphate. Concentrations of $\left(\mathrm{NH}_{4}\right)_{2} \mathrm{SO}_{4}$ and $\mathrm{GSH}$ added before freeze-drying were $25 \%$ of saturation and $4 \mathrm{~mm}$ respectively.

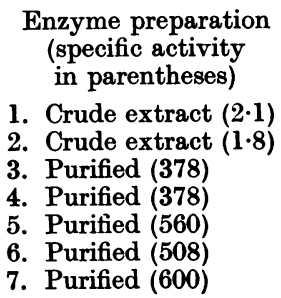

Enzyme preparation (specific activity in parentheses

2. Crude extract $(\mathbf{1} \cdot \mathbf{8})$

5. Purified (560)

6. Purified (508)

7. Purified (600)

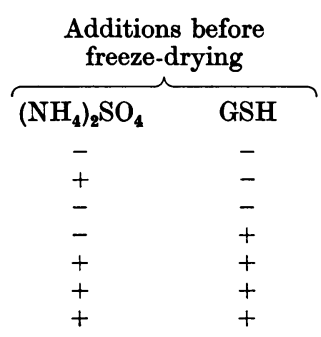

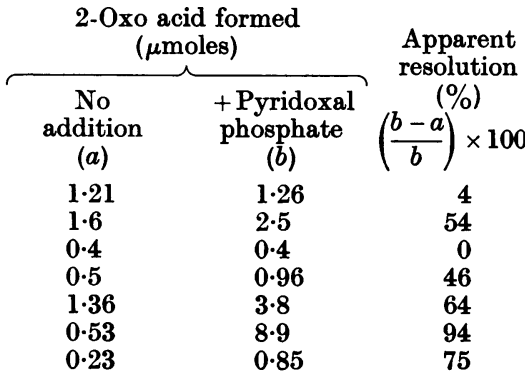


AMP added together or separately increased the activity of the preparation, but addition of pyridoxal phosphate (final concentration $20 \mu \mathrm{M}$ ) doubled the activity. If pyridoxal phosphate and GSH were added together (final concentrations $20 \mu \mathrm{M}$ and $\mathrm{mM}$ respectively), the activity was in-

Table 5. Effect of glutathione, adenosine 5-phosphate and pyridoxal phosphate on a partially resolved enzyme preparation

A $75 \%$-resolved enzyme preparation $(0.1 \mathrm{ml}$.) was incubated at $37^{\circ}$ for $20 \mathrm{~min}$. with $0.5 \mathrm{ml}$. of $0.1 \mathrm{~m}$-borate buffer, pH 9.5, $0.2 \mathrm{ml}$. of $0.1 \mathrm{M}$-L-threonine, with GSH (1 $\mu \mathrm{mole})$, AMP (1 $\mu$ mole) and pyridoxal phosphate $(10 \mu \mathrm{g}$.$) added$ where indicated.

$\begin{array}{ccccc}\begin{array}{c}\text { Expt. } \\ \text { no. }\end{array} & \overbrace{}^{\text {GSH }} & \text { AMP } & \begin{array}{c}\text { Pyridoxal } \\ \text { phosphate }\end{array} & \begin{array}{c}\text { 2-Oxo acid } \\ \text { formed } \\ (\mu \text { mole })\end{array} \\ 1 & - & - & - & 0.06 \\ 2 & + & - & - & 0.06 \\ 3 & - & + & - & 0.06 \\ 4 & - & - & + & 0.13 \\ 5 & + & - & + & 0.33 \\ 6 & + & + & - & 0.06 \\ 7 & - & + & + & 0.06 \\ \text { Control } & + & - & + & 0 \\ \text { (no substrate) } & & & & \end{array}$

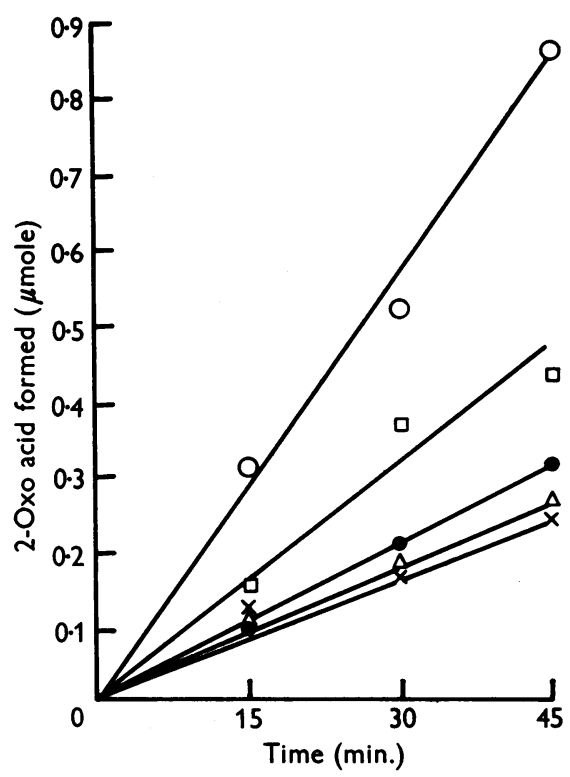

Fig. 2. Effect of pyridoxal phosphate concentration on production of 2-oxo acid by a partially resolved enzyme preparation. Reaction mixture contained $0.5 \mathrm{ml}$. of $0.1 \mathrm{M}$-borate buffer, $\mathrm{pH} 9.5,0.2 \mathrm{ml}$. of $0.1 \mathrm{M}$-L-threonine, $0.1 \mathrm{ml}$. of $0.01 \mathrm{~m}-\mathrm{GSH}$ and $0.1 \mathrm{ml}$. of partially resolved enzyme preparation. Pyridoxal phosphate was added to the concentrations indicated. Total volume $1.2 \mathrm{ml}$. Pyridoxal phosphate concentrations: $\times$, none; $\triangle$, $0.2 \mu \mathrm{M} ; 0,0.4 \mu \mathrm{M} ; \square, 4 \mu \mathrm{M} ; \bigcirc, 400 \mu \mathrm{M}$. creased more than fivefold (Table 5). No explanation is offered for the inhibition by AMP of the pyridoxal activation, but it is interesting to note that Yanofsky \& Reissig (1953) observed the same effect with the Neurospora enzyme.

Effect of pyridoxal phosphate concentration. An enzyme preparation with an apparent resolution of $75 \%$ (preparation 7, Table 4) was used to study the effect of pyridoxal phosphate concentration in the presence of $10 \mathrm{~mm}$-GSH, and excess of substrate (Fig. 2). The values for initial rate of keto acid production have been corrected by subtraction of the value obtained in absence of added pyridoxal phosphate, and the velocities so obtained used to obtain a rough measure of the $K_{m}$ value by the method of Lineweaver \& Burk (1934). This treatment is valid if it is assumed that the added pyridoxal phosphate does not influence the activity of the undissociated enzyme-coenzyme complex. The $K_{m}$ obtained (1.8 $\left.\mu \mathrm{M}\right)$ represents the apparent dissociation constant of the pyridoxal phosphate from the apoenzyme.

\section{DISCUSSION}

Umbarger \& Brown (1957) showed that when crude extracts of $E$. coli were treated with hydroxylamine according to the procedure described by Roberts (1952), the threonine deaminase was inactivated and that preparations so treated were reactivated by pyridoxal phosphate. Yanofsky \& Reissig (1953), using purified preparations of Neurospora L-threonine deaminase, and Sayre \& Greenberg (1956) using the sheep-liver enzyme, have also shown a requirement for pyridoxal phosphate.

The experiments reported here provide the first clear-cut evidence for a pyridoxal phosphate requirement by a purified, bacterial L-threonine deaminase.

The method employed for the dissociation of the apoenzyme-coenzyme complex is empirical; it was based on the finding that a crude extract treated similarly, and for another purpose, was partially resolved with respect to pyridoxal phosphate. No explanation can, as yet, be offered for the function of ammonium sulphate. The most obvious explanation of the role of GSH is that it protects essential sulphydryl groups.

The $K_{m}$ value obtained for the pyridoxal phosphate-apoenzyme system is probably not a true indication of the affinity of the apoenzyme for its coenzyme, since the latter is obviously tightly bound to its protein, and the Michaelis-Menten theory assumes a freely dissociable complex. However, the value obtained (1.8 $\mu \mathrm{M}$-pyridoxal phosphate) serves to characterize the preparation, and is in reasonable agreement with that of $0.4 \mu \mathrm{M}$ given by Yanofsky \& Reissig (1953) for the same system in Neurospora.

Bioch. 1958, 69 
Optimum deamination of threonine proceeds

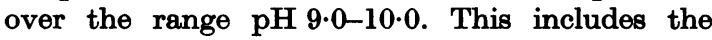
optimum $\mathrm{pH}$ of 9.3 for the Neurospora enzyme (Yanofsky \& Reissig, 1953). Sayre \& Greenberg (1956) reported that the optimum $\mathrm{pH}$ for the sheep-liver enzyme was 7.4.

L-Serine appears to be deaminated in LC 1 by the same enzyme which acts upon L-threonine, a finding in agreement with the work by Umbarger \& Brown (1957) on the $E$. coli enzymes and Yanofsky \& Reissig (1953) with Neurospora. In contrast, Sayre \& Greenberg (1956) demonstrated that two easily separated enzymes were present in sheep liver: one specific for $\mathrm{L}$-serine and the other for L-threonine.

The $K_{m}$ values for L-threonine and L-serine were 3.0 and $6.8 \mathrm{~mm}$ respectively. These figures are similar to those found by Yanofsky \& Reissig (1953) for the Neurospora enzyme, and by Wood \& Gunsalus (1949) for the deamination of L-threonine by $E$. coli extracts. The sheep-liver enzyme has a lower affinity for its substrate $\left(K_{m}=29 \mathrm{~mm}\right.$; Sayre \& Greenberg, 1956).

\section{SUMMARY}

1. The L-threonine deaminase of the rumen micro-organism LC1 was purified over 100-fold from extracts of vacuum-dried cells by successive fractionation with protamine sulphate and ammonium sulphate, gradient elution with ammonium sulphate and fractionation on a calcium phosphate gel-cellulose column.

2. The enzyme has an optimum $\mathrm{pH}$ in the range 9.0-10.0. $K_{m}$ values of $6.8 \mathrm{~mm}$ and $3.0 \mathrm{~mm}$ were obtained for L-serine and L-threonine respectively. D-Threonine appeared to inhibit the enzyme.

3. The ratio of L-serine deaminase activity to Lthreonine deaminase activity varied little at different stages of the purification, suggesting that one enzyme attacks both substrates.
4. The purified enzyme, after freeze-drying in the presence of ammonium sulphate or glutathione, required pyridoxal phosphate. Glutathione also appeared to be necessary for maximum activity.

I wish to express my thanks to Dr S. R. Elsden for his continued interest and advice and to Dr J. L. Peel for permission to publish his method for large-scale culture of LC. This work was supported in part by the Rockefeller Foundation. I also wish to acknowledge the receipt of a Research Studentship from the Agricultural Research Council.

\section{REFERENCES}

Conway, E. J. \& O'Malley, E. (1942). Biochem. J. 38, 655. Dixon, M. (1953). Biochem. J. 54, 457.

Elsden, S. R. \& Lewis, D. (1953). Biochem. J. 55, 183.

Elsden, S. R., Volcani, B. E., Gilchrist, F. M. C. \& Lewis, D. (1956). J. Bact. 72, 681.

Friedemann, T. E. \& Haugen, G. E. (1943). J. biol. Chem. $147,415$.

Keilin, D. \& Hartree, E. F. (1936). Proc. Roy. Soc. B, 119, 114. Lewis, D. \& Elsden, S. R. (1955). Biochem. J. 60, 683.

Lineweaver, H. \& Burk, D. (1934). J. Amer. chem.Soc. 56, 658.

McIntire, W. M., Palmer, G. \& Marshall, H. L. (1945). Biochem. J. 48, 171.

Metzler, D. E. \& Snell, E. E. (1952). J. biol. Chem. 198, 363.

Roberts, E. (1952). J. biol. Chem. 198, 495.

Robertson, W. B. (1942). Science, 96, 93.

Sayre, F. W. \& Greenberg, D. M. (1956). J. biol. Chem. 220, 787.

Schwimmer, S. (1953). Nature, Lond., 171, 443.

Shinn, L. A. \& Nicolet, B. H. (1941). J. biol. Chem. 138, 91.

Stadtman, E. R. \& Barker, H. A. (1949). J. biol. Chem. 180, 1085.

Stadtman, E. R., Novelli, G. D. \& Lipmann, F. (1951). J. biol. Chem. $191,365$.

Swingle, S. M. \& Tiselius, A. (1951). Biochem. J. 48, 171.

Umbarger, H. E. \& Brown, B. (1956). J. Bact. 71, 443.

Umbarger, H. E. \& Brown, B. (1957). J. Bact. 73, 105.

Umbreit, W. W., Burris, R. H. \& Stauffer, J. F. (1949). In Manometric Techniques and Tissue Metabolism, p. 173. Minneapolis: Burgess Publishing Co.

Walker, D. J. (1957). Biochem. J. 67, 4 P.

Wood, W. A. \& Gunsalus, I. C. (1949). J.biol. Chem.181, 171. Yanofsky, C. \& Reissig, J. L. (1953). J. biol. Chem. 202, 567

\title{
Condensed Tannins
}

\section{A STUDY OF COMPLEX LEUCO-ANTHOCYANINS PRESENT IN CONDENSED TANNINS}

\author{
BY D. G. ROUX AND S. R. EVELYN \\ Leather Industries Research Institute, Rhodes University, Grahamstown, South Africa
}

\section{(Received 16 December 1957)}

Condensed tannins are widely distributed in Nature, and constitute a heterogeneous group possessing the common characteristic of forming insoluble 'phlobaphenes' on treatment with hot dilute mineral acids in aqueous medium. This rather general characteristic is shared by the catechins, which occur in high proportion in association with tannins in some commercial tanning extracts, e.g. cube gambier from the leaves of Uncaria gambir and cutch from the heartwood of Acacia catechu. Freudenberg \& Maitland (1934) and Freudenberg \& Weinges (1955) 